\title{
Overview of Plant-Derived Vaccine Antigens: Dengue Virus
}

\author{
Ravindra B. Malabadi ${ }^{1}$, Advaita Ganguly ${ }^{1}$, Jaime A. Teixeira da Silva ${ }^{2}$, Archana Parashar ${ }^{1}$, Mavanur R. Suresh ${ }^{1}$, Hoon \\ Sunwoo $^{1}$ \\ ${ }^{1}$ Faculty of Pharmacy and Pharmaceutical Sciences, University of Alberta, Edmonton, Canada. \\ ${ }^{2}$ Faculty of Agriculture and Graduate School of Agriculture, Kagawa University, Miki-cho, Kagawa-ken, Japan.
}

Received, September 2, 2011; Revised, October 2, 2011, Accepted October 19, 2011, Published October 20, 2011.

\begin{abstract}
This review highlights the advantages and current status of plant-derived vaccine development with special reference to the dengue virus. There are numerous problems involved in dengue vaccine development, and there is no vaccine against all four dengue serotypes. Dengue vaccine development using traditional approaches has not been satisfactory in terms of inducing neutralizing antibodies. Recently, these issues were addressed by showing a very good response to inducing neutralizing antibodies by plant-derived dengue vaccine antigens. This indicates the feasibility of using plant-derived vaccine antigens as a low-cost method to combat dengue and other infectious diseases. The application of new methods and strategies such as dendritic cell targeting in cancer therapy, severe acute respiratory syndrome, tuberculosis, human immune deficiency virus, and malaria might play an important role. These new methods are more efficient than traditional protocols. It is expected that in the near future, plant-derived vaccine antigens or antibodies will play an important role in the control of human infectious diseases.
\end{abstract}

This article is open to POST-PUBLICATION REVIEW. Registered readers (see "For Readers") may comment by clicking on ABSTRACT on the issue's contents page.

Abbreviations: ADE: antibody-dependent enhancement, AmB: amphotericin B, bsMAb: bispecific antibody, DC: dendritic cells, DEN-2: dengue virus serotype 2, DENVs: dengue virus serotypes, FDA: Federal Drug Administration, IMAC: immomobilized-metal affinity chromatography, KDEL: endoplasmic reticulum-retention signal, MV: measles vaccine, NS1: non-structural protein, PDVA: plant-derived vaccine antigen, SARS: severe acute respiratory syndrome, TMV: Tobacco mosaic virus, TSP: total soluble protein, USDA: United States department of agriculture

\section{INTRODUCTION}

The success story of any immunization programme depends upon the efficacy of the vaccine (1-4). For many reasons, developing countries can not afford to produce expensive vaccines $(1,2,5,6)$. There are many issues associated with the production of vaccines that have been widely reviewed and discussed (1-4). Traditional vaccines are produced by the application of fermentation technology in various cell culture systems. However, there are many limitations involved with fermentation so that development of alternative systems for the production of vaccines is timely $(1-3,5,6)$. Plants have been used as herbal drugs for millenia; they also play an important role in modern medicine. Recent advances in the area of plant biotechnology have revealed many achievements, including the production of desired vaccine antigens in plants (4, 7-16). The use of plants for the production of vaccines has many advantages, which have been previously discussed $(1,2,4,6,13,14,15,17-22)$. Plant cells also play an important role in the accumulation of foreign proteins in specialized cell compartments, allowing for the retention of native biological activity $(7,21,23-27)$. There are many established and published protocols in the literature for the isolation of protein from plant tissues. Purification of an antigenic protein from plant cell culture is very simple since the antigenic protein is histidine-tagged and can be separated using an immomobilized-metal affinity chromatography (IMAC) system. Plants are considered to be effective alternative production systems for subunit vaccines as they are likely to contribute to all of these critical features of effective vaccines $(12,14$, 28-33). The strategy for the production of plant-

\footnotetext{
Corresponding Author: M. R. Suresh, or R.B. Malabadi, Faculty of Pharmacy and Pharmaceutical Sciences, University of Alberta, 11304-89 Avenue, Edmonton, Canada. msuresh@pharmacy.ualberta.ca.
} 
derived vaccine antigen (PDVA) against human infectious diseases is diagrammatically presented in Figure 1. Furthermore, plants are photoautotrophic and use light as their energy source, unlike mammalian or insect cell culture growth, resulting in a more robust and inert system for the production of subunit vaccines in different plant systems (4, 34). Several plant-derived vaccines have been through Phase I and II clinical trials in humans and are increasingly developed $(4,13,15)$. Plantderived vaccines constitute a technology with proven worth as a cheap and easy means to scale-up the production of valuable materials $(7,15,21,26$, $27,35)$. The production of antigenic protein in plants affects protein yield. The yields of PDVA can be as high as $45 \%$ of a plant cell's total protein compared to that of vaccines produced from a mammalian cell culture system (36). Thus far, several plant species, including potato, tobacco, tomato, Arabidopsis, soybean, alfalfa, lettuce, lupin, rice, banana, grapes, watermelon, black-eyed bean, cowpea, and corn have been used for production of vaccine antigens against dengue, tuberculosis, human immune deficiency virus (HIV), foot and mouth disease, hepatitis virus B surface antigen, cholera toxin B, severe acute respiratory syndrome (SARS), Norwalk virus capsid protein, avian influenza (H5N1 subtype), swine fever, malaria, diabetes-type 1 , human papilloma virus, rotavirus, and smallpox recombinant vaccine virus $(3-5,30-$ $33,37,38)$. Separately, the use of a magnifection system increased the total soluble protein accumulation level of hepatitis B virus (HB core) in tobacco by more than $7 \%(6,39-41)$. Plant-derived vaccines (PDVs) could soon be on the market due to many advantages. This is mainly due to the established plant tissue culture protocols for many commercial plants, as well as established gene cloning and plant transformation technology (42). A number of factors may modulate gene expression in plants, including: appropriate codon optimization popularized by Geneart Inc., Germany, Integrated DNA Technologies (IDT), USA, Biobasic Inc., Canada, Abnova Inc., Taiwan; promoter, leader and polyadenylation signals.

A very powerful tool in biotechnology is genetic transformation and transgenic plants represent a potentially stable and cheap propagation source for the production of a protein of pharmaceutical interest such as a vaccine (42-46). This is achieved by the transfer of a foreign gene of interest into the nuclear or organelle (chloroplast) genome of the plant to generate transgenic plants that express the antigenic protein $(3,34,47-48)$. Transgenic plants are most commonly obtained by Agrobacterium-mediated gene transfer or by bombardment with DNA coated high velocity gold/tungsten particles (43, 49-53), both followed by an appropriate plant tissue culture regeneration methods either via organogenesis or somatic embryogenesis (54-65). Therefore, the successful application of plant tissue culture techniques and genetic transformation plays an important role in the production of PDVs.

\section{GLYCOENGINEERING}

Plant and mammalian glycosylation are not similar (7, 12, 22, 66-67). The covalent attachment of sugar molecules to proteins in glycosylation has improved folding capacity, biological activity and solubility (2223, 68-69). Proteins produced by plants lack the terminal galactose and sialic acid residues commonly found in animals and have $\alpha-(1,3)$ fucose and $\beta-(1,2)$ xylose which are absent in mammalian systems $(7,22$, 70). Recently these issues have been addressed by the application of genetic engineering techniques (22). On the other hand, PDVAs have shown higher immunogenicity than other expression systems $(7,22$, 38). However, the immunogenicity of plant glycans is still of major concern in the context of plant proteins $(7,21,22,26,27,71)$. Furthermore, 13 (1, 4)-galactosyltransferase is one of the key enzymes that plays an important role in the glycosylation pathway $(7,22,71)$. Production of transgenic tobacco resulted in $15 \%$ of proteins expressing terminal $(1,4)$-galactose residues $(7,21,22,71)$. Various methods have been adopted to modify the N-glycosylation pattern in plants $(68,69,72,73)$. Therefore, plants could be used for the production of glycosylated proteins for the development of vaccine antigens against human diseases (68, 69, 74).

\section{COMMERCIALIZATION AND CLINICAL TRIALS}

Plant-derived vaccines will likely replace traditional vaccines in the pharmaceutical industry in the future $(6,15,38,39,68,69)$. A review article published by Tiwari and co-workers (15) highlighted the outcome and results of most 


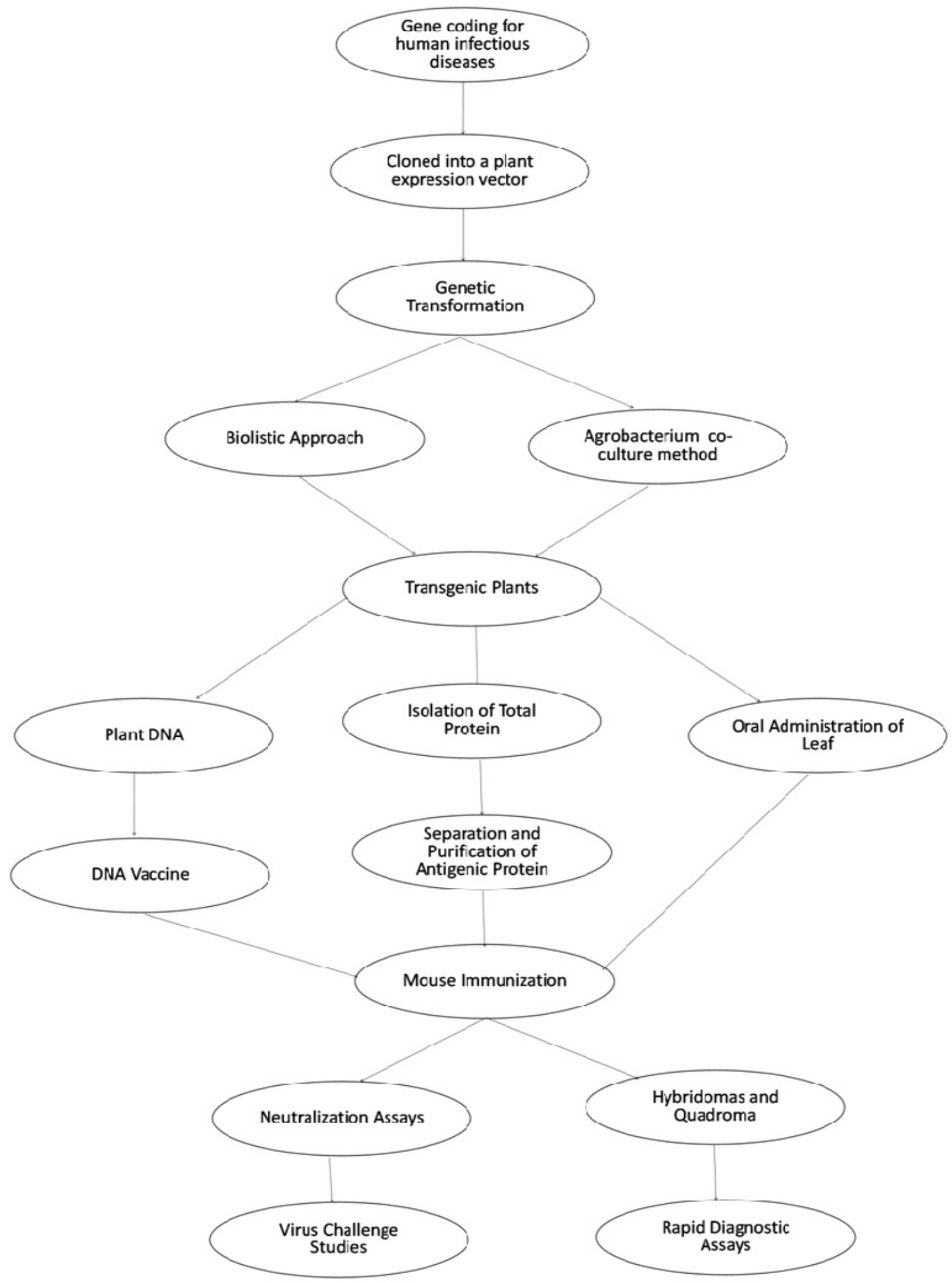

Figure 1. Schematic Representation of Strategies for the development of Plant derived vaccines and diagnostics 
clinical trials of plant-derived vaccines. Our paper updates that review with some more information on clinical trials. On the basis of published reports, PDVAs were successful during phase I clinical trials $(15,69)$. There are many plant-derived vaccines that, during clinical trials, induced neutralizing antibodies following immunization $(9,15,44-46,68,69,75,76,77,78)$. A US-based company (Dow Agro Sciences LLC) received regulatory approval for a plant-made vaccine from the US Department of Agriculture (USDA) Centre for Veterinary Biologists in $2006(15,68)$. This plant culture-derived veterinary vaccine antigen that protects poultry from Newcastle disease (www.thepoultrysite.com) also met the requirements of the FDA $(15,68,69)$. In another development, a Canadian-based company from Calgary, SemBioSys Inc., has completed Phase II trials of insulin produced in transgenic safflower (Carthamus tinctorius L.), and has filed an Investigational New Drug Application with the FDA, and submitted a Clinical Trial Application to European authorities $(38,79)$. Medicago Inc. (Canada) are currently undergoing Phase II trials for their avian influenza vaccine produced transiently in tobacco (Nicotiana tobaccum), after receiving clearance from Health Canada $(38,80)$. Taliglucerase alfa produced in stable carrot cell cultures is used to treat Gaucher disease. Protalix Bio-Therapeutics has just completed a Phase III trial and the product was approved by the FDA. Furthermore, the FDA has also accepted a New Drug Application and granted a Prescription Drug User Act action date in early $2011(38,81)$. Therefore, results of clinical trials have already confirmed the potential of transgenic plant biotechnology in diagnostic and therapeutic industry.

\section{DENGUE EXPRESSION SYSTEMS: CASE STUDIES}

Dengue is one of the major causes of mosquitoborn viral disease of humans reported in different regions of the world (82-87). The World Health Organization (WHO) estimates that approximately more than 2.5 billion people are at risk of getting infected with dengue $(82,84,86-91)$. In some countries, dengue disease has become the leading cause of death among children (82-84, 92-98).

Different expression systems (bacterial, mammalian, baculovirus, and yeast) have been used for the production of dengue antigenic protein from various laboratories around the world. Bacterial expression is one of the most commonly employed expression systems for the production of recombinant proteins $(99,147)$. A gene fragment from the structural envelope glycoprotein $\mathrm{E}$ and the non-structural protein (NS1) of dengue virus serotype 2 (DEN-2) was expressed in E. coli as a fusion protein with Staphylococcal protein A (100). The expressed protein was found to be immunogenic against dengue 2 virus in a mouse model (100). Hermida and co-workers (101) immunized Macaca fascicularis monkeys with two variants of these proteins [PD3 (insertion variant) and PD5 (fusion variant)] corresponding to serotype 2 of dengue disease. The results of this study confirmed the induction of immunity in a nonhuman primate model by using Escherichia coli as the expression platform (101). In another development, Khanam and coworkers (102) developed a recombinant adenovirus capable of expressing the E domain III (EDIII) of DEN-2 and evaluated its potential as a dengue vaccine (102). This study also showed the induction of antibodies that specifically neutralized the infectivity of DEN-2 virus (102). Furthermore, the dengue antigenspecific antibody titers elicited by the fusion protein (Domain II of Mycobacterium tuberculosis (Mtb) heat shock protein 70 (HSP70), was covalently linked to a recently described synthetic dengue virus antigen), and successfully expressed in E. coli (103). A higher rate of anti-dengue antibodies were produced in mice than those induced by either the synthetic dengue antigen alone or a physical mixture of the dengue antigen plus Mtb HSP70 domain II protein (103). A recombinant vaccine strain SL3261/pLT105 of attenuated aroA Salmonella enterica serovar Typhimurium SL3261 strain expressing a secreted (DEN-2) non-structural NS1 and Yersinia pestis F1 (Caf1) fusion protein, rNS1:Caf1, was developed to test its immunological potential via a prime boost vaccine regimen (104). The addition of an antifungal antibiotic amphotericin B (AmB) to Salmonella vaccine further boosted the synergic effects of prime-boost vaccine regimen on the elicited NS1-specific serum IgG response and the protective efficacy (104). Therefore, this study clearly demonstrated the potential of amphotericin $\mathrm{B}(\mathrm{AmB})$ as an effective strategy for dengue vaccine development (104). Furthermore, a bacterial (E. coli) expression system 
has been utilized to study the immunogenicity and protective capacity of a recombinant capsid protein from dengue-2 virus (105). The results of that study also demonstrated the protective capacity of the capsid protein of dengue virus indicating the existence of a protector mechanism totally independent of the antibodies (105).

The immunomodulatory potential of refolded dengue (D4EIII) protein in combination with various adjuvants (Freund's Complete adjuvant, Montanide ISA720, Alum) has been reported by Babu and coworkers (106). All the formulations resulted in high antibody titers that neutralized the virus entry in vitro (106). D4EIII, in combination with montanide ISA720 and Freund's complete adjuvant, gave highest antibody endpoint titers followed by alum (106). Therefore, this study demonstrated the recombinant D4EIII protein expressed in $E$. coli induced neutralizing antibodies and cell-mediated immune response in immunized animals in combination with different adjuvants (106). On the other hand, Sim and coworkers (107) noted that mucosal vaccines present several advantages over conventional vaccines, including their ease of administration and low cost (107). Their study showed that the antibody's response depended on the route of administration and on the mouse strain inoculated (107).

A simple and significant method for the expression of NS1 in E. coli has been demonstrated to develop monoclonal and bispecific antibodies for dengue point of care diagnostics (99). An E. coli codon-optimized synthetic full-length NS1 gene of dengue serotype 1 (DEN-1) was successfully cloned and expressed at very high levels as inclusion bodies (99). The rNS1 protein was used to immunize mice for hybridoma development (99). The polyclonal antiserum from animals immunized with this rNS1 protein was found to specifically reorganize the rNS1, thus demonstrating the immunogenic nature of the protein (99). The rNS1 protein purified from E. coli could be useful for developing a sensitive serum diagnostic assay to monitor dengue outbreaks (99). Dengue NS1 antigen testing is one of the important tools for the early diagnosis of dengue infection after the onset of fever (99). Commercially available dengue NS1 antigen capture ELISA has been evaluated for the detection of NS1 from patients in different stages. It is therefore, an important antigen for rapid viral diagnosis $(99,108)$.
Khanam and co-workers (109) successfully produced a tetravalent vaccine against dengue disease by mixing four monovalent vaccine components (109). This vector induced effective immune responses and virus-neutralizing antibodies specific to each of the four dengue virus serotypes (DENVs) in mice (109). Interestingly, anti-AdV5 antibodies did not suppress the induction of DENV-specific neutralizing antibodies (109). Therefore, it could be an alternative approach for the development of a single component tetravalent vaccine that bypasses the complexities inherent in the currently adopted four-in-one physical mixture approach (109). Very recently, Block and coworkers (110) evaluated the high yield insect cell expression, neutralizing and enhancing antibody response to E domain III (dIII) proteins of dengue virus in which serotype-specific neutralizing determinants were concentrated (110). Therefore, vaccine strategies directed to DENV-dIII-targeted neutralizing antibody production remain attractive (110). In another development, Brandler and coworkers (111) evaluated for the first time a new strategy based on the expression of a single minimal tetravalent DV antigen by a single replicating viral vector derived from pediatric liveattenuated measles vaccine (MV) (111). That study reports the successful induction of neutralizing antibodies against DENVs (111). Hence, this study concluded the possibility of a combined measles-dengue vaccine, which might be feasible to immunize infants against both diseases (111). In another study by Batra and coworkers (112), biotinylated chimeric dengue antigens have been used to exploit the high affinity of the biotin-streptavidin interaction for the detection of anti-dengue antibodies (112). On the other hand, Ramanathan and co-workers (113) highlighted two major problems in the development of a dengue vaccine: failure of a neutralization effect and the unequal presentation of antigens against DENVs (113). This study also revealed the problems of allergic or varying levels of immune responses against dengue in different patients (113). These problems have led many to consider the effectiveness of PDVAs and also DNA vaccines as a potential platform for the development of a dengue vaccine. Therefore, a PDVA against dengue would be immunogenic and offer protection from the disease. The ability 
to induce neutralizing antibodies against DENVs disease with a single immunogen is a significant advantage.

\section{RELEVANCE OF PLANT-DERIVED VACCINE AGAINST DENGUE}

Despite decades of efforts, no licensed vaccine for dengue disease is currently available on the world market $(84,113,114)$. Vaccine development would be a major concern because dengue virus infections have led to the death of many people and now it is a major economic issue, especially in developing countries $(84,114,115)$. The development of a dengue virus vaccine is difficult, because every serotype provides life-long immunity, but infection with a heterologus virus enhances the disease severity $(113,114,115)$. This phenomenon is called antibody-dependent enhancement (ADE), and occurs often in children born to dengue-immune mothers (114). A tetravalent vaccine with low reactogenicity would be an effective choice of treatment $(113,114,115)$. Several groups attempted to develop a vaccine, including live attenuated viruses, chimeric viruses, recombinant subunit antigens, vector-based vaccines and DNA vaccines. The Dengue E glycoprotein has been produced in several heterologous expression systems such as $E$. coli $(116,117)$, Pichia pastoris $(118,119)$, and baculovirus (120) with appropriate yields of the antigenic and immunogenic dengue $2 \mathrm{E}$ protein. However, the expression level of the full length or ectodomain of the dengue $2 \mathrm{E}$ protein is low in mammalian or insect cells or the expressed protein is easily degraded (115). In addition, the existing expression systems have failed to show antibody neutralizing activity against DEN-2. To explore alternative expression systems, it is necessary to evaluate the production of dengue antigenic protein in plant cell culture and in transgenic plants. Recently a gene fragment encoding domain III of the dengue 2 envelope protein (D2EIII) was successfully expressed in a model plant system Nicotiana benthamiana using a Tobacco mosaic virus (TMV)-based transient expression system (121-123). The intramuscular immunization of mice with D2EIII induced the production of the antibodies against dengue (121-123). The induced antibodies demonstrated neutralizing activity against DEN-2 $(121,122)$. The results indicate that the plant system produces the dengue virus antigen, which possesses appropriate antigenicity and immunogenicity $(121,122)$. Therefore, transgenic plants demonstrate the feasibility of using PDVs to prevent infection by the dengue virus $(121,122)$.

Saejung and co-workers (121) reported the successful induction of anti-dengue virus antibody as well as an anti-D2EIII antibody production in mice by utilizing the $N$. benthamiana-recombinant TocJ, a TMV-based viral vector, as a bioreactor system to produce the D2EIII protein (121). The yield of purified D2EIII protein was $0.28 \%$ of total soluble protein TSP (121). The high expression level of D2EIII was achieved by a combination of several factors, including targeting the protein to the endoplasmic reticulum (ER) by the signal peptide and 5' UTR (121). During the study conducted by Saejung and co-workers (121), it was also noticed that the higher the level of anti-dengue virus antibody, the higher the neutralizing antibody activity in the sera of immunized mice, which was directly correlated with the anti-dengue virus antibody level and the neutralizing antibody activity of the immunized mouse antisera (121). The level of induction of immunized-mouse antisera to the dengue virus antigen was low (121). A low level of anti-dengue virus antibody induction might be due to the small antigenic fragments resulting in insufficient induction of high antibody production, even though an adjuvant was used in the experiment (121). No antibody induction was detected when mice were immunized with plantproduced D2EIII protein without adjuvant (121). Immunized mice induced neutralizing antibodies, with plant-produced D2EIII protein with Titer Max Gold adjuvant many times and for a long period (121). Therefore, vaccine development should focus on high-level induction of neutralizing antibodies (121). Furthermore, the titer of the neutralizing antibody induced by the plant-produced D2EIII protein was not high, but was quite promising (121). The neutralizing antibody titer can be increased by changing the antigen dose, route of immunization, or by using other adjuvants (121). The advantage of using TocJ-TMV as an expression system are a high yield of a foreign protein up to $10 \%$ of TSP in infected leaves, a short time required for protein expression, and low toxicity (121). In another study by Kim and co-workers (122), the plant-produced domain III of dengue virus E glycoprotein (EIII) was between 0.13 and $0.25 \%$ of the total soluble protein in transgenic $N$. 
tabacum L. cv. 'MD609' under the control of the $35 \mathrm{~S}$ promoter (122). This study demonstrated the feasibility of using plant-based vaccines to prevent infection by the dengue virus (122). A truncated version of dengue virus envelope glycoprotein (Eprotein) was designed and expressed alone and coexpressed with dengue virus structural proteins (122). The recombinant proteins were produced in $N$. benthamiana plants and were reactive with the anti-E antibody (123). The fusion was reactive with both anti-E and anti-HB core antibodies (123). Some studies have shown that Flavivirus envelope glycoprotein produced in different expression systems undergoes proteolytic degradation (124). However, Martínez and co-workers (123) reported the absence of any discernible low MW protein when expressed in an $N$. benthamiana system, indicating that there are no plant proteolytic degradation events (123). They also demonstrated that the dengue virus envelope glycoprotein (Eprotein) truncated version with a KDEL retention signal or co-expressed with other structural proteins in plants was not subjected to such a degradation process (123). The level of protein accumulation was estimated and expressed protein equalled 0.6 $\mathrm{mg} / \mathrm{g} \mathrm{FW}$ leaf at $7 \mathrm{dpi}$, CMEt at $0.5 \mathrm{mg} / \mathrm{g} \mathrm{FW}$ leaf at $10 \mathrm{dpi}$ and $\mathrm{HB}$ core-dengue virus envelope glycoprotein (E-protein) at $0.4 \mathrm{mg} / \mathrm{g} \mathrm{FW}$ leaf at 7 dpi (123). Furthermore, the production of domain III of the DEN-2 envelope protein in tobacco plants using a TMV transient expression system is safe for humans and the environment (123). N. benthamiana is a non-food crop in which foreign proteins are subsequently purified or processed to yield desirable products $(34,42,121-123)$.

\section{DENDRITIC CELL TARGETING STRATEGIES FOR DENGUE}

Dendritic cells (DCs) have been identified as the most specialized and potent antigen presenting cells capable of initiating and directing immune responses following infection (125-133). Wang and co-workers $(131,132)$ developed a bifunctional fusion protein (bsmAb) that can bind any class of biotinylated antigen proteins, peptides, carbohydrates, gangliosides and even naked DNA and target them to a DEC-205 receptor molecule which is expressed on DCs (131). In another study, biologically active plant-derived medicines have been identified with DC-modulating properties
(133). Plant-derived medicines play an important role as immunomodulators of DCs for the maintenance of human health (133). In many infectious and cancerous situations, priming immune responses to a single antigen may not be sufficient for effective immune responses (131, 132). Therefore, a universal DC-targeting vehicle such as bispecific or bifunctional antibody (bsMAb or bfMAb, respectively) that can bind to a mixture of biotinylated plant-derived antigens would be the best approach to elicit the immune response against dengue $(82,131,132,134,135,136,137-146)$. Therefore, PDVA presentation by DC targeting might play an important role in eliciting a good immune response with efficient neutralizing antibodies against dengue.

\section{LIMITATIONS OF PDVAS}

PDVAs have many challenges. The major limitation of this system is the relatively low protein yield, protein degradation and incorrect post-translational modifications of protein $(3,15$, 22). Recently, these issues have been addressed by improving the protein expression levels in plants by some important steps by using ER retention signal sequences like KDEL and HDEL, by the use of a proper promoter, choice of vectors, methods of transformation, and codon optimization (22). Development of codon-optimized genes for plants during expression studies has improved protein yields up to $200 \mathrm{mg} / \mathrm{g} \mathrm{FW}$ of tobacco tissue. Recently, the yield of purified dengue 2E III protein was $0.28 \%$ total soluble protein (TSP). This high expression level was achieved by a combination of several factors viz. by inserting the plant signal peptide at the $\mathrm{N}$-terminal end, and $\mathrm{C}$-terminal ER retention sequence for plants (121). Expression of protein in the ER has drastically reduced the degradation of expressed protein (antigen) and resulted in a higher yield of protein accumulation $(12,15,22)$. Gene silencing issues are another major problem during the expression of vaccine antigenic proteins in transgenic plants. This is resolved by the use of Agrobacterium, which tends to result in fewer copies of transgenes than biolistic transformation $(15,22,43)$. Biosafety, risk assessment, and public acceptance of transgenic plants producing vaccine antigens are other issues. These issues have been widely discussed by other researchers and are beyond the scope of this review 
paper. Furthermore, cross contamination of transgenic plants with other food crops was resolved by applying containment approach technology, thus limiting the environmental exposure of transgenic products $(15,22)$. The slow growth of plants under in vitro conditions has also hindered the commercialization of PDVAs. This is particularly related to the regeneration of transgenic plants under in vitro conditions. This issue is solved by the manipulation of media, growth conditions and plant growth regulator concentration to develop a reproducible plant tissue culture protocol before considering the right candidate for genetic transformation.

\section{CONCLUDING REMARKS}

Production of a vaccine antigen against dengue, an infectious disease, is one of the serious problems due to many issues. There are many disadvantages associated with the traditional production of vaccine antigens. This situation has forced many scientists throughout the world for the production of PDVA against many human infectious diseases including dengue. Recently many private companies and government agencies throughout world have also joined hands and funded many projects on the PDVAs in order to meet current demands of the immunization programmes particularly in the developing countries. DC targeting approach using PDVA may play an important role. This would help in the early diagnostic tests in the patients suffering from dengue infection. On the other hand, in many instances, plants will replace the traditional mammalian system as a cost effective vaccine production system against dengue. This would also save of money in developing countries because of high budget of health care programmes. Therefore, the plants seem to be a superior expression system, and plant biotechnology has a bright future.

\section{ACKNOWLEDGEMENTS}

We warmly acknowledge the National Sciences and Engineering Research Council (NSERC) of Canada - strategic funding in the preparation of this review on dengue, which is one of the ongoing projects at the Faculty of Pharmacy and Pharmaceutical Sciences, University of Alberta, Edmonton, Canada.

\section{REFERENCES}

1. Davoodi-Semiromi A, Samson N, Daniell H. The green vaccine: A global strategy to combat infectious and autoimmune diseases. Hum vaccines, 2009; 5(7): 488-493.

2. Davoodi-Semiromi A, Schreiber M, Nallapali S, Verma D, Singh ND, Banks RK, Chakrabarti D, Daniell H. Chloroplast-derived vaccine antigens confer dual immunity against cholera and malaria by oral or injectable delivery. Plant Biotech J, 2010; 8(2): 223-242.

3. Daniell H, Singh ND, Mason H, Streatfield SJ. Plant-made vaccine antigens and biopharmaceuticals. Trend Plant Sci, 2009; 14(12): 669-679.

4. Rybicki EP. Plant-made vaccines for humans and animals. Plant Biotech J, 2010; 8: 620-637.

5. Bock R, Warzecha H. Solar-powered factories for new vaccines and antibiotics. Trends Biotech, 2010; 28(5): 246-252.

6. Gomez E, Zoth SC, Carrillo E, Berinstein A. Developments in plant-based vaccines against diseases of concern in developing countries. The Open Infect Dis J, 2010; 4: 55-62.

7. Ma JKC, Drake PMW, Chargelegue D, Obregon P, Prada A. Antibody processing and engineering in plants, and new strategies for vaccine production. Vaccine, 2005; 23: 1814-1818.

8. Obregon P, Chargelegue D, Drake PMW, Prada A, Nuttall J, Frigerio L, Ma JKC. HIV-1 p24immunoglobulin fusion molecule: a new strategy for plant-based protein production. Plant Biotech J, 2006; 4: 195-207.

9. Thanavala Y, Yang YF, Lyons P, Mason HS, Arntzen C. Immunogenicity of transgenic plantderived hepatitis B-surface antigen. Proc Nat Acad Sci USA, 1995; 92: 3358-3361.

10. Korban SS. Targeting and expression of antigenic proteins in transgenic plants for production of edible oral vaccines. In Vitro Cell Dev Biol - Plant, 2002; 38: 231-236.

11. Hiatt A, Cafferkey R, Bowdish K. Production of antibodies in transgenic plants. Nature, 1989; 342: 76-78.

12. Hellwig S, Drossard J, Twyman RM, Fischer R. Plant cell cultures for the production of recombinant proteins. Nat Biotech, 2004; 22 (11): 1415-1422.

13. Vermij P, Waltz E. USDA approves the first plantbased vaccine. Nat Biotech, 2006; 24: 233-234.

14. Malabadi RB. Production of edible vaccines for oral immunization in transgenic plants, current and future prospective. J Phytol Res, 2008; 21(1): 1-10. 
15. Tiwari S, Verma PC, Singh PK, Tuli R. Plants as bioreactors for the production of vaccine antigens. Biotech Advan, 2009; 27: 449-467.

16. Malabadi RB, Parashar A, Ganguly A, Suresh MR. Expression of Dengue virus envelope protein in a different plant system. Faculty Research and Development day, Faculty of Pharmacy and Pharmaceutical Sciences, University of Alberta, Edmonton, Canada, $19^{\text {th }}$ November 2010. Abstract No-69, page no-31.

17. Walmsley AM, Arntzen CJ. Plant cell factories and mucosal vaccines. Curr Opin Biotech, 2003; 14:145-150.

18. Pascual DW. Vaccines are for dinner. Proc Nat Acad Sci USA, 2007; 104(26): 10757-10758.

19. Lal P, Ramachandran VG, Goyal R, Sharma R. Edible vaccines: Current status and future. Ind $\mathrm{J}$ Med Microbiol, 2007; 25 (2): 93-102.

20. Giddings G, Allison G, Brooks D, Carter A. Transgenic plants as factories for biopharmaceuticals. Nat Biotech, 2000; 18(11): 1151-1155.

21. Ma S, Huang Y, Yin Z, Menassa R, Brandle JE, Jevnikar AM. Induction of oral tolerance to prevent diabetes with transgenic plants requires glutamic acid decarboxylase (GAD) and IL-4. Proc Nat Acad Sci USA, 2004; 101: 5680-5685.

22. Desai PN, Shrivastava N, Padh H. Production of heterologous proteins in plants: strategies for optimal expression. Biotech Adv, 2010; 28: 427435.

23. Lienard D, Sourrouille C, Gomord V, Faye L. Pharming and transgenic plants. Biotech Ann Rev, 2007; 13:115-147.

24. Mason HS, Lam DM, Arntzen CJ. Expression of hepatitis B surface antigen in transgenic plants. Proc Nat Acad Sci USA, 1992; 89: 11745-11749.

25. Mason HS, Ball JM, Shi JJ, Jiang X, Estes MK, Arntzen CJ. Expression of Norwalk virus capsid protein in transgenic tobacco and potato and its oral immunogenicity in mice. Proc Nat Acad Sci USA, 1996; 93: 5335-5340.

26. Ma S, Zhao DL, Yin ZQ, Mukherjee R, Singh B, Qin HY. Transgenic plants expressing auto antigens fed to mice to induce oral immune tolerance. Nat Med, 1997; 3: 793-796.

27. Ma JK, Hikmat BY, Wycoff K, Vine ND, Chargelegue $\mathrm{D}, \mathrm{Yu}$ L. Characterization of a recombinant plant monoclonal secretory antibody and preventive immunotherapy in humans. Nat Med, 1998; 4: 601-606.

28. Goldstein DA, Thomas JA. Biopharmaceuticals derived from genetically modified plants. Oxf $\mathrm{J}$ Med, 2004; 97: 705-716.

29. Haq TA, Mason HS, Clements JD, Arntz CJ. Oral immunization with a recombinant bacterial antigen produced in transgenic plants. Science, 1995; 268: 714-716.

30. Chen X and Liu J. Generation and immunogenicity of transgenic potato expressing the GP5 protein of porcine reproductive and respiratory syndrome virus. J Virol Meth, 2011; 173(1): 153-158.

31. Phoolcharoen W, Bhoo SH, Lai H, Ma J, Arntzen CJ, Chen Q, Mason HS. Expression of an immunogenic Ebola immune complex in Nicotiana benthamiana. Plant Biotech J, 2011; (still in press).

32. Farrance $\mathrm{CE}$, Chichester JA, Musiychuk $\mathrm{K}$, Shamloul M, Rhee A, Manceva SD, Jones RM, Mamedov T, Sharma S, Mett V, Streatfield SJ, Roeffen W, Vegte-Bolmer MV, Sauerwein RW, Wu Y, Muratova O, Miller L, Duffy P, Sinden R, Yusibov V. Antibodies to plant-produced Plasmodium falciparum sexual stage protein Pfs25 exhibit transmission blocking activity. Hum Vaccines, 2011; 7: 191-198.

33. Mathew LG, Maloney B, Takeda N, Mason HS. Spurious polyadenylation of Norovirus Narita 104 capsid protein mRNA in transgenic plants. Plant Mol Biol, 2011; 75(3): 263-75.

34. Tremblay R, Wang D, Jevnikar AM, Ma S. Tobacco, a highly efficient green bioreactor for production of therapeutic proteins. Biotech Adv, 2010; 28: 214-221.

35. Arakawa T, Chong DKX, Langridge WHR. Efficacy of a food plant-based oral cholera toxin B subunit vaccine. Nat Biotech, 1998; 16: 292-297.

36. Hefferon KL. The mucosal immune response to plant-derived vaccines. Pharma Res, 2010; 27: 2040-2042.

37. Shoji Y, Chichester JA, Jones M, Manceva SD, Damon E, Mett V, Musiychuk K, Bi H, Farrance C, Shamloul M, Kushnir N, Sharma S, Yusibov V. Plant-based rapid production of recombinant subunit hemagglutinin vaccines targeting H1N1 and H5N1 influenza. Hum Vaccine, 2011; 7: 41-50.

38. Penney CA, Thomas DR, Deen SS, Walmsley AM. Plant-made vaccines in support of the Millennium Development Goals. Plant Cell Rep, 2011; 30: 789798.

39. Yusibov V, Rabindran S. Recent progress in the development of plant derived vaccine. Exp. Rev. Vaccines, 2008; 7: 1173-1183.

40. Gleba Y, Klimyuk V, Marillonnet S. Magnifectiona new platform for expressing recombinant vaccines in plants. Vaccine, 2005; 23: 2042-2048.

41. Huang Z, Santi L, LePore K, Kilbourne J, Arntzen CJ, Mason HS. Rapid, high level production of hepatitis B core antigen in plant leaf and its immunogenicity in mice. Vaccine, 2006; 24: 25062513. 
42. Sala F, Rigano MM, Barbante A, Basso B, Walmsley AM, Castiglione S. Vaccine antigen production in transgenic plants: strategies, gene constructs and perspectives. Vaccine, 2003; 21(7\&8): 803-808.

43. Malabadi RB, Nataraja K. Genetic transformation of conifers: Applications in and Impacts on commercially forestry. Trans Plant J, 2007a; 1(2): 289-313.

44. Tacket CO. Plant derived vaccines against diarrheal diseases. Vaccine, 2005; 23: 1866-1869.

45. Tacket CO, Mason HS, Losonsky G, Estes MK, Levine MM, Arntzen CJ. Immunogenicity in humans of a recombinant bacterial antigen delivered in transgenic potato. Nat Med, 1998; 4: 607-609.

46. Tacket CO, Mason HS, Losonsky G, Estes MK, Levine MM, Arntzen CJ. Human immune responses to a novel Norwalk virus vaccine delivered in transgenic potatoes. J Inf Dis, 2000; 182: 302-305.

47. Maliga P. Plastid transformation in higher plants. Ann Rev Plant Biol, 2004; 55: 289-313.

48. Bally J, Nadal M, Vitel M, Rolland A, Dumain R, Dubald M. Plant physiological adaptations to the massive foreign protein synthesis occurring in recombinant chloroplasts. Plant Physiol, 2009; 150: 1474-1481.

49. Malabadi RB, Nataraja K. Stable transformation and recovery of transgenic plants by particle bombardment in $P$. wallichiana A. B. Jacks (Himalayan blue pine). Biotechnology, 2007b; 6: 105-111.

50. Malabadi RB, Teixeira da Silva JA, Nataraja K. Agrobacterium tumefaciens-mediated genetic transformation of $P$. kesiya Royle ex Gord (Khasi pine). Asian Australasian J Plant Sci Biotech, 2008a; 2(1): 7-14.

51. Malabadi RB, Teixeira da Silva JA, Nataraja K. Stable and consistant Agrobacterium-mediated genetic transformation in $P$. roxburghii (Chir pine). Tree For Sci Biotech, 2008b; 2(1): 7-13.

52. Malabadi RB,Teixeira da Silva JA, Nataraja K. A new approach involving salicyclic acid and thin cell layers for cloning mature trees of Pinus roxburghii (Chir Pine). Am J Plant Sci Biotech, 2008c; 2(2): 56-59.

53. Malabadi RB, Teixeira da Silva JA, Nataraja K. Green fluorescent protein in the genetic transformation of plants. Trans Plant J, 2008d; 2(2): 86-109.

54. Malabadi RB, Nataraja $\mathrm{K}$. In vitro plant regeneration in Clitoria ternatea. J Med Arom Plant Sci, 2002; 24: 733-737.

55. Malabadi RB, Choudhury H, Tandon P. Initiation, maintenance and maturation of somatic embryos from thin apical dome sections in Pinus kesiya (Royle ex. Gord) promoted by partial desiccation and gellan gum. Sci Hortic, 2004; 102: 449-459.

56. Malabadi RB, Mulgund GS, Nataraja K. Micropropagation of Dendrobium nobile from shoot tip sections. J. Plant Physiol 2005; 162:473478.

57. Malabadi RB, van Staden J. Somatic embryogenesis from vegetative shoot apices of mature trees of P. patula. Tree Physiol, 2005a; 25: 11-16.

58. Malabadi RB, van Staden J. Role of antioxidants and amino acids on somatic embryogenesis of $P$. patula. In Vitro Cell Deve Biol-Plant, 2005b; 41: 181-186.

59. Malabadi RB, van Staden J. Storability and germination of sodium alginate encapsulated somatic embryos derived from vegetative shoot apices of mature Pinus patula trees. Plant Cell Tiss Org Cult, 2005c; 82: 259-265.

60. Malabadi RB, Nataraja K. Cryopreservation and plant regeneration via somatic embryogenesis using shoot apical domes of mature Pinus roxburghii Sarg. Trees. In vitro Cell Dev Biol - Plant, 2006; 42 (2): 152-159.

61. Malabadi RB, Teixeira da Silva JA. Thin cell layers: Application to forestry biotechnology. Tree For Sci Biotech, 2011; 5(SI1): 14-18.

62. Malabadi RB, Teixeira da Silva JA, Mulgund GS. Induction of somatic embryogenesis in Pinus caribaea. Tree For Sci Biotech, 2011; 5(SI1): 2732.

63. Malabadi RB, Mulgund GS, Nataraja K. Triacontanol induced somatic embryogenesis and plantlet regeneration in Catharanthus roseus. J Med Arom Plant Sci, 2009; 31: 147-151.

64. Malabadi RB, Mulgund GS, Vijaykumar S. Expression of WUSCHEL-gene promoting somatic embryogenesis in plants. J Phytol Res, 2009; 22 (1): 103-106.

65. Malabadi RB, Teixeira da Silva JA, Mulgund GS. TDZ-induced in vitro shoot regeneration of Aerides maculosum Lindl. From shoot tip thin cell layers. Floriculture Ornamental Biotech, 2009; 3(1): 35-39.

66. Palacpac NQ, Yoshida S, Sakai H, Kimura Y, Fujiyama K, Yoshida T, Seki T. Stable expression of human b1, 4-galactosyltransferase in plant cells modifies N-linked glycosylation patterns. Proc Nat Acad Sci USA, 1999; 96: 4692-4697.

67. Bosch D, Schots A. Plant glycans: friend or foe in vaccine development? Exp Rev Vaccine, 2010; 9(8): 835-842.

68. Obembe OO,Popoola JO, Leelavathi S,Siva V. Reddy SV. Advances in plant molecular farming. Biotech Adv, 2011; 29(2): 210-222. 
69. Obembe OO.The plant biotechnology flight: Is Africa on board? Afr J Biotech, 2010; 9(28): 43004308.

70. Sethuraman N, Stadheim TA. Challenges in therapeutic glycoprotein production. Curr Opin Biotech, 2006; 17(4): 341-346.

71. Bakker H, Bardor M, Molthoff JW, Gomord V, Elbers I, Stevens LH. Galactose-extended glycans of antibodies produced by transgenic plants. Proc Nat Acad Sci USA, 2001; 98: 2899-2904.

72. Koprivova A, Stemmer C, Altmann F, Hoffmann A, Kopriva S, Gorr G. Targeted knockouts of Physcomitrella lacking plant-specific immunogenic $\mathrm{N}$-glycans. Plant Biotech J, 2004; 2: 517-523.

73. Kang JS, Frank J, Kang CH, Kajiura H, Vikram M, Ueda A. Salt tolerance of Arabidopsis thaliana requires maturation of $\mathrm{N}$-glycosylated proteins in the Golgi apparatus. Proc Natl Acad Sci USA, 2008; 105: 5933-5938.

74. Castilho A, Strasser R, Stadlmann J, Grass J, Jez $\mathrm{J}$, Gattinger P. In planta protein sialyation through overexpression of the respective mammalian pathway. J. Biol Chem, 2010; 285: 15923-15930.

75. Kapusta J, Modelska A, Figlerowicz M, Pniewski $\mathrm{T}$, Letellier M, Lisowa O. A plant derived edible vaccine against hepatitis B virus. FASEB J, 1999; 13:1796-1799.

76. Lamphear BJ, Jilka JM, Kesi L, Welter M, Howard JA, Streatfield SJ. A corn-based delivery system for animal vaccines: an oral transmissible gastroenteritis virus vaccine boosts lactogenic immunity in swine. Vaccine, 2004. 22: 2420-2424.

77. Basaran P, Rodriguez-Cerezo E. Plant molecular farming; opportunities and challenges. Crit Rev Biotech, 2008; 28:153172.

78. McCormik AA, Palmer KE. Genetically engineered tobacco mosaic virus as nanoparticle vaccines. Exp. Rev. Vaccines, 2008; 7: 33-41.

79. SemBioSys. SemBioSys provides update on insulin program. Press release. Retrieved 12 Dec 2010.

http://micronewswire.ca/release.cgi? rkey $=17040$ $16279 \&$ view $=36078-0 \&$ Start $=30 \& \mathrm{htm}=0$.

80. Medicago. Medicago receives regulatory approval and commences Phase II clinical testing of its avian influenza vaccine. Press release. Retrieved 12 Dec 2010. http://www.medicago.com/ English/news/News-Releases/News-Release Details/2010/Medicago-Receives-RegulatoryApproval-and-CommencesPhase-II-ClinicalTesting-of-its-Avian-Influenza-Vaccine1123044/ default.aspx (Nov 1, 2010).
81. Protalix BioTherapeutics. ProtalixBio Therapeutics announces preliminary top-line positive data from Taliglucerase alfa switchover trial. Press release. Retrieved 12 Dec 2010. http://phx.corporate-ir.net/phoenix.zhtml?c= 10116 $1 \& \mathrm{p}=$ irol-newsArticle \&ID=1490071\&highlight $=$ (Nov 2, 2010).

82. Murrell S, Wu S-C, Butler M. Review of dengue virus and the development of a vaccine. Biotech Adv, 2011; 29: 239-247.

83. Schieffelin JS, Costin JM, Nicholson CO, Orgeron NM, Fontaine KA, Isern S, Michael SF, Robinson JE. Neutralizing and non-neutralizing monoclonal antibodies against dengue virus $\mathrm{E}$ protein derived from a naturally infected patient. Virol J, 2010; 7: (28) $1-11$.

84. Shrivastava A, Dash PK, Tripathi NK, Sahni AK, Gopalan N, Lakshmana Rao PV Evaluation of a commercial Dengue NS1 enzyme-linked immunosorbent assay for early diagnosis of dengue infection. Ind J Med Mirobiol, 2011; 29(1): 51-55.

85. Monath TP. Dengue: the risk to developed and developing countries. Proc Nat Acad Sci USA, 1994; 85: 7627-7631.

86. Halstead SB. Pathogenesis of dengue: challenges to molecular biology. Science, 1988; 239(4839): 476481.

87. Halstead SB. Antibody, macrophages, dengue virus infection, shock, and hemorrhage: a pathogenic cascade. Rev. Infect. Dis, 1989; 11(4): S830-9.

88. World Health Organization. W.P. R. Dengue in the Western Pacific Region (online). http.//www.wpro.who.int/health_topics/dengue/ove rview.htm 2010.

89. World Health Organization. Vector borne viral infections: dengue fever (online). $\mathrm{http}$ //www.who.int/vaccine_research/diseases/vect or/en/index 1.html. 2009.

90. Gubler DJ, Meltzer M. Impact of dengue/dengue hemorrhagic fever on the developing world. Adv Virus Res, 1999; 53: 35-70.

91. Simasathien S, Watanaveeradej V. Dengue vaccine. J Med Assoc Thai, 2005; 88(3): S363-77.

92. Holmes E, Twiddy SS. The origin, emergence and evolutionary genetics of dengue virus. Inf Gen Evol, 2003; 3: 19-28.

93. Rico-Hesse R. Molecular evolution and distribution of dengue viruses type 1 and 2 in nature. Virology, 1990; 174(2): 479-93.

94. Sabin AB. Research on dengue during World War II. Am J Trop Med Hyg, 1989; 1(1): 30-50.

95. Henchal EA, Putnak JR. The dengue viruses. Clin Microb Rev, 1990; 3(4):376-396.

96. Perez-Velez ME, Garcia-Nieves T, Colon-Sánchez C, Martínez I. Induction of neutralization antibodies 
in mice by dengue- 2 envelope DNA vaccines. PR Health Sci J 2009; 28(3): 239-250.

97. Swaminathan S, Batra G, Khanna N. Dengue vaccines: state of the art. Exp Opin Therap Pat, 2010; 20(6): 819-835.

98. Cardosa MJ. Dengue vaccine design: issues and challenges. Brit Med Bull, 1998; 54 (2): 395-405.

99. Das D, Mongkolanngkoon S, Suresh MR. Super induction of dengue virus NS1 protein in E. coli. Prot Exp Purification, 2009; 66: 66-72.

100. Srivastava AK, Putnak JR, Warren RL, Hoke Jr $\mathrm{CH}$. Mice immunized with a dengue type-2 virus $\mathrm{E}$ and NS1 fusion protein made in E. coli are protected against lethal dengue virus infection. Vaccine, 1995; 13: 1251-1258.

101. Hermida L, Bernardo L, Martín J, Mayling Alvarez M, Prado I, López C, Sierra BDC, Martínez R, Rodríguez R, Zulueta A, Pérez AB, Lazo L, Rosario D, Guillén G, Guzmán MG. A recombinant fusion protein containing the domain III of the dengue-2 envelope protein is immunogenic and protective in nonhuman primates. Vaccine, 2006; 24: 31653171.

102. Khanam S, Khanna N, Swaminathan S. Induction of neutralizing antibodies and $\mathrm{T}$ cell responses by dengue virus type 2 envelope domain III encoded by plasmid and adenoviral vectors. Vaccine, 2006; 24: 6513-6525.

103. Kolli R, Khanam S, Jain M, Ganju L, Sai Ram M, Khanna N, Swaminathan S. A synthetic dengue virus antigen elicits enhanced antibody titers when linked to, but not mixed with, Mycobacterium tuberculosis HSP70 domain II. Vaccine, 2006; 24: 4716-4726.

104. Liu WT, Lin WT, Tsai CC, Chuang CC, Liao CL, Lin HC, Hung YW, Huang SS, Liang CC, Hsu HL, Wang HJ, Liu YT. Enhanced immune response by amphotericin B following NS1 protein prime-oral recombinant Salmonella vaccine boost vaccination protects mice from dengue virus challenge. Vaccine, 2006; 24: 5852-5861.

105. Lazo L, Hermida L, Zulueta A, Sánchez J, Lopez C, Silva R, Guillen G, Guzmán MG. A recombinant capsid protein from Dengue-2 induces protection in mice against homologous virus. Vaccine, 2007; 25: 1064-1070.

106. Babu JP, Pattnaik P, Nimesh Gupta N, Shrivastava A, Khan M, Lakshmana PV, Rao L. Immunogenicity of a recombinant envelope domain III protein of dengue virus type-4 with various adjuvants in mice. Vaccine, 2008; 26: 4655-4663.

107. Sim ACN, Lin W, Tan GKX, Sim MST, Chow VTK, Alonso $\mathrm{S}$. Induction of neutralizing antibodies against dengue virus type 2 upon mucosal administration of a recombinant Lactococcus lactis strain expressing envelope domain III antigen. Vaccine, 2008; 26: 11451154.

108. Kumarasamy V, Wahb AH, C, Chua SK, Hassan Z, Chem YK, Mohamad M, Chua KB. Evaluation of a commercial dengue NS1 antigen-capture ELISA for laboratory diagnosis of acute dengue virus infection. J Virol Meth, 2007; 140: 75-79.

109. Khanam S, Pilankatta R, Khanna N, Swaminathan S. An adenovirus type 5 (AdV5) vector encoding an envelope domain III-based tetravalent antigen elicits immune responses against all four dengue viruses in the presence of prior AdV5 immunity. Vaccine, 2009; 27: 6011-6021.

110. Block OKT, Shanaka WW, Rodrigo I, Quinn M, Jin X, Rose RC, Schlesinger JJ. A tetravalent recombinant dengue domain III protein vaccine stimulates neutralizing and enhancing antibodies in mice. Vaccine, 2010; 28: 8085-8094.

111. Brandler S, Ruffie C, Najburg V, Frenkiel MP, Bedouelle H, Despres P, Frederic-Tangy F. Pediatric measles vaccine expressing a dengue tetravalent antigen elicits neutralizing antibodies against all four dengue viruses. Vaccine, 2010; 28: 6730-6739.

112. Batra G, Talha SM, Nemani SK, Dhar N, Swaminathan S, Khanna N. Expression, purification and characterization of in vivo biotinylated dengue virus envelope domain III based tetravalent antigen. Prot Exp Purification, 2010; 74: 99-105.

113. Ramanathan MP, Kuo YC, Selling BH, Li Q, Sardesai NY, Kim JJ, Weiner DB. Development of novel DNA SynConTM tetravalent dengue vaccine that elicts immune response against four seoryptes. Vaccine, 2009; 27: 6444-6453.

114. Alan MMF, Kaptein SJF, Burghgraeve TD, Balzarini J, Neyts J, Schols D. Antiviral activity of carbohydrate-binding agents and the role of DCSIGN in dengue virus infection. Virology, 2009; 387: 67-75.

115. Yap YK, Smith DR. Strategies for the plant-based expression of dengue subunit vaccines. Biotech Appl Biochem, 2010; 57(2): 47-53.

116. Sugrue RJ, Cui T, Xu Q, Fu J, Chan YC. The production of recombinant dengue virus $\mathrm{E}$ protein using Escherichia coli and Pichia pastoris. J Virol Meth, 1997; 69(1/2): 159-169.

117. Jaiswal S, Khanna N, Swaminathan S. High level expression and one step purification of recombinant dengue virus type 2 envelope domain III protein in Escherichia coli. Prot Exp Purification, 2004; 33 (1): 80-91.

118. Wei H-Y, Jiang L-F, Xue Y-H, Fang D-Y, Guo HY. Secreted expression of dengue virus type 2 fulllength envelope glycoprotein in Pichia pastoris. J Virol Meth, 2003; 109(1):17-23. 
119. Bisht H, Chugh DA, Swaminathan S, Khanna N. Expression and purification of dengue virus type 2 envelope protein as a fusion with hepatitis B surface antigen in Pichia pastoris. Prot Express Purification, 2001; 23(1): 84-96.

120. Kelly EP, Greene JJ, King AD, Innis BL. Purified dengue 2 virus envelope glycoprotein aggregates produced by baculovirus are immunogenic in mice. Vaccine, 2000; 18 (23): 2549-2559.

121. Saejung W, Fujiyama K, Takasaki T, Ito M, Hori $\mathrm{K}$, Malasit $\mathrm{P}$, Watanabe $\mathrm{Y}$, Kurane I, Seki T. Production of dengue 2 envelope domain III in plant using TMV-based vector system. Vaccine, 2007; 25: 6646-6654.

122. Kim MY, Yang MS, Kim TG. Expression of dengue virus $\mathrm{E}$ glycoprotein domain III in nonnicotine transgenic tobacco plants. Biotech Biop Eng, 2009; 14: 725-730.

123. Martinez CA, Topal E, Giulietti AM, Talou JR, Mason H. Exploring different strategies to express dengue virus envelope protein in a plant system. Biotech Lett, 2010; 32: 867-875.

124. Guirakhoo F, Heinz FX, Kunz C. Epitope model of tick borne encephalitis virus envelope glycoprotein E: analysis of structural properties, role of carbohydrate side chain and conformational changes occurring at acidic pH. Virology, 1989; 169: 90-99.

125. Inaba K, Swiggard WJ, Inaba M, Meltzer A, Sasagawa T, Nussenzweig MC, Steinman RM. Tissue distribution of the DEC-205 protein that is detected by the monoclonal antibody NLDC-145: I. Expression on dendritic cells and other subsets of mouse leukocytes. Cell Immunol, 1995; 163: 148153.

126. Jiang W, Swiggard WJ, Heufler C, Peng M, Mizra A, Steinman RM, Nussenzwig MC. The receptor DEC-205 expressed by dendritic cells and thymic epithelial cells is involved in antigen processing. Nature, 1995; 375: 151.

127. Banchereau J, Steinman RM. Dendritic cells and the control of immunity. Nature, 1998; 392: 245.

128. Den Haan JM, Lehar SM, Bevan MJ. CD8 (+) but not CD8 (-) dendritic cells cross-prime cytotoxic T cells in vivo. J Exp Med, 2000; 192: 1685-1689.

129. Nestle FO, Banchereau J, Hart D. Dendritic cells: on the move from bench to bedside. Nat Med, 2001; 7: 761 .

130. Cerundolo V, Hermans IF, Salio M (2004) Dendritic cells: a journey from laboratory to clinic. Nat Immunol, 2004; 5: 7.

131. Wang WW, Das D, Tang XL, Budzynski W, Suresh MR. Antigen targeting to dendritic cells with bispecific antibodies. J Immunol Meth, 2005; 306: 80-92.
132. Wang WW, Das D, Suresh MR. A versatile bifunctional dendritic cell targeting vaccine vector. Mol Pharma, 2009; 6(1): 158-172

133. Licciardi PV, Underwood JR. Plant-derived medicines: A novel class of immunological adjuvants. Int. Immunopharma, 2010; 11(3): 390398.

134. Suresh MR, Cuello AC, Milstein C. Advantages of bispecific hybridomas in one step immunocytochemistry and immunoassays. Proc Nat Acad Sci USA, 1986a; 83: 7989-7993.

135. Suresh MR, Cuello AC, Milstein C. Bispecific monoclonal antibodies from hybrid hybridomas. Meth Enzymology, 1986b; 121: 210-215.

136. Husereau DR, Suresh MR. A general affinity method to purify peroxidase-tagged antibodies. J Imm Meth, 2001; 249: 33-41.

137. Cao Y, Suresh MR. Bispecific antibodies as novel bioconjugates. Biocon Chem, 1998; 9(6): 635-644.

138. Bhatnagar PK, Das D, Suresh MR. Sequential affinity purification of peroxidase tagged bispecific anti-SARS-CoV antibodies on phenylboronic acid agarose. J Chrom B, 2008; 863: 235-241.

139. Kammila S, Das D, Bhatnagar PK, Sunwoo HH, Zayas-Zamora G, King M, Suresh MR. A rapid point of care immunoswab assay for SARS-CoV detection. J Virol Meth, 2008; 152:77-84.

140. Kreutz FT, Suresh MR. Novel bispecific immunoprobe for rapid and sensitive detection of prostate-specific antigen. Clin Chem, 1997; 43(4): 649-656.

141. Guttikonda S, Tang XL, Yang BM, Armstrong GD, Suresh MR. Monospecific and bispecific antibodies against E. coli 0157 for diagnostics. J Immunol Meth, 2007; 327:1-9.

142. Magee WC, Shahhosseini S, Lin YCJ, Suresh MR, Evans DH. Production and characterization of antibodies against vaccinia virus DNA polymerase. J Immunol Meth, 2009; 161:44-51.

143. Tang XL, Peppler MS, Irvin RT, Suresh MR. Use of bispecific antibodies in molecular Velcro assays whose specificity approaches the theoretical limit of immunodetection for Bordetella pertussis. Clin Diag Lab Immunol, 2004; 11(4): 752-757.

144. Shahhosseini S, Das D, Qiu X, Feldmann H, Jones SM, Suresh MR. Production and characterization of monoclonal antibodies against different epitopes of Ebola virus antigens. J Immunol Meth, 2007; 143: 29-37.

145. Liu F, Guttikonda S, Suresh MR. Bispecific monoclonal antibodies against a viral and an enzyme: utilities in ultrasensitive virus ELISA and phage display technology. J Immunol Meth, 2003; 274: 115-127. 
146. Cao Y, Christian S, Suresh MR. Development of a bispecific monoclonal antibody as a universal immunoprobe for detecting biotinylated macromolecules. J Immunol Meth, 1998; 220: 85-91.
147. Simmons LC, Reilly D, Klimowski L, Raju TS, Meng G, Sims P. Expression of full-length immunoglobulins in Escherichia coli: rapid and efficient production of aglycosylated antibodies. J Immunol Meth, 2002; 263: 133-147. 